\title{
Communication Norms in NGOs Advocating Reproductive Health: A Comparative Study of Malaysian and Nigerian NGOs
}

\author{
Mumtaz Ali \\ Department of Sociology, University of Sindh, Jamshoro, Pakistan \\ Maya Khemlani David \\ Asia-Europe Institute, University of Malaya, Malaysia \\ Angela Rumina Leo \\ School of Education \& Social Sciences, Management \& Science University, Malaysia
}

\begin{abstract}
Reproductive health is an emerging issue in developing countries. The United Nations Population Fund (UNFPA) reports that every minute, a woman in the developing world dies from treatable complications of either pregnancy or childbirth. Nigeria is a country where the state of reproductive health of its population is dismal. In 2012, UNFPA pointed out that Nigeria has one of the worst maternal mortality statistics in the world with a maternal mortality ratio of 545 per 100,000 live births. Several NGOs around the world deliver services at various levels to advocate the right of mothers to have safe births as well as address the shortage of skilled midwives. In this context, Malaysia has done much to control its infant and maternal mortality rates, through its community reproductive health initiatives. This study then aims to determine the communication norms in two NGOs, one in Malaysian and the other in Nigeria. The analysis was of projects undertaken by two NGOs, the Federation of Reproductive Health Association of Malaysia (FRHAM) and the Association for Reproductive and Family Health (ARFH) of Nigeria. The communication norms and ways of getting the community involved in their projects were examined through progress reports, document review and web searches. Besides being interviewed, questionnaires were filled by the employees of the NGOs. The findings indicate that the Nigerian and Malaysian NGOs have different communication models and they can learn from each other's best practices.
\end{abstract}

Key words: $N G O$, communication norms, reproductive health, Malaysia, Nigeria,

\section{Introduction}

Without any single definition, all the non-government organizations (NGO) share crime free engagements, nonpolitical grounds, and independence from the direct control of the government. Candland (2001) highlights that alternatively known as the Civil Society Organizations (CSO), these non-profit bodies serve as the agents of social change, mediators and growth practitioners. Despite these major players in global health development have become increasingly professionalized over the last three decades, they are widely identified in reference to the principles of altruism as typically mission-driven organizations that are dependent on humanitarian aids and voluntary services, either partially or fully. The NGOs who play a vital role to support community health initiatives and run various projects for the welfare in addition, to the betterment of people (Hilhorst, 2003; Goldberger, 2008), are also open to joining hands with the government through a public-private partnership (Amin, 2009).
The officials who work in these organizations and serve marginalized segments of society (Edwards, 1994; Smith, 1999 et al); impelled by diverse blends of compassion, sacrifice, self-interest and vanity; (Nour, 2011) shape the NGOs via out-reach activities carried out according to their understanding of the needs of local circumstances (Rule \& Kyle, 2008; Ruth, 2006; Salim, Sadruddin, et al, 2011). Nevertheless, the impact of their works on communities depends upon relationships and the smooth communication flow in organization and their external systems. Here, it is noteworthy to remember that effective communication encompassing both charitable officials and community participation ensures their involvement in organizational decisions, which in turn aids in proper management of these community projects.

Communication is the lifeblood for every organization and NGOs are not an exception, especially for the actualization of their social works among communities (Tanova, 2010; Komito, 2007). Since the triumph of any enrichment project depends on community participation, the implication of effectual communication between NGOs and communities is 


\section{Yinternational Research Journal}

p-ISSN 2202-2821 e-ISSN 1839-6518 (Australian ISSN Agency)

simply undeniable (Terri \& Jennifer, 2006). In fact, the larger the number of community members engaged in the advocacy, the more efficacious; communication needs to be in an NGO. Moreover, only if the NGOs exercise potent communication and coordination with donor organizations and philanthropists, can they generate lots of funding comfortably and further mobilize legislative bodies to ensure that their work serves the interests of the poor and neglected (Scholes, 1998; Donna, Sonia et al. 2008).

Participation of personnel in organizational decisions and community involvement in field activities increases association, which then supports project management and ensures transparency in the projects besides creating a reciprocal working environment in this globalized world (Scholes, 1998). However, in reality it is quite difficult to comprehend the model of communication among members of the NGOs (Hilhorst, 2003). Although at the managerial level, community relations run fluidly, maintaining effective communication flow within an organization remains a challenge for NGO leadership.

Internationally, the NGOs are expected to be in the vanguard, trans-positioning reproductive health as a fundamental issue in populace and upgrading especially in low resource settings through health service delivery, promotion, and policy advocacy. Moreover, a growing body of literature on the role and effectiveness in the reproductive health sector has accompanied the proliferation of these NGOs (Budden, 2010). However, research concerning the efficiency of communication norms in such NGOs seems to be scanty, as a premium has not been placed upon operative communication, which in turn has resulted in poor organizational management.

This study then strives significantly to address the core issue of these NGOs by identifying their potential communicative practices; particularly in Malaysia and Nigeria, investigating the similarities and differences of communication norms in both these NGOs, and further highlighting the key to successful action in low resource settings. This analysis covers the four key functions of management communication; particularly knowledge and information sharing, consultation and decision-making, communication, and networking.

\section{II.Literature Review}

\section{State of Reproductive Health: Malaysia vs Nigeria}

Poverty is one of the major challenges for developing countries (Roni, 2009). In spite of being one of the most successful third world nations in terms of economic development, the bearings of the commercial expansion in
Vol. 10 No. 012020

82801001202007

the rural Malaysia are limited; chiefly in the reproductive health sector. Burger (2012) stressed that in these remote areas, less than half of the women $(42.9 \%)$ are of normal weight, $35.7 \%$ suffer from chronic energy deficiency (CED), $7.1 \%$ (one) are overweight, and $14.3 \%$ are obese. This scenario, which negatively contributes towards the reproductive health of female villagers, magnifies the existing need to run more awareness programs for women to take multi-vitamin, proper diet and minerals. The FRHAM (2013) emphasizes that in the aim of securing longevity, accurate and comprehensive information on reproductive health must be provided from an early age, even though sexual health issues are exposed to young girls through the chapter on reproductive health in the secondary school syllabus (Mian, 1998; Lim, 1998). Rahman (2011) states that in the inadequate numbers of studies conducted concerning reproductive health in Malaysia, findings feature a lack of consciousness among the youth on reproductive health and suggest that there is a necessity to increase the level of sexual and reproductive health knowledge among adolescents.

On the other hand, a demographic health report presents the high fertility level in Nigeria with a total fertility rate (TFR) of 5.7 which hint at that an average Nigerian woman will bear approximately six children in her lifetime and underlines that if the situation persists, the population of Nigeria will be doubled; risking its socio-economic status. This is mainly due to misconceptions about family planning, large family size, methods, and male child preference. In addition, the UNFPA (2013) reports that every minute, a woman in the lower-middle income country dies from curable complications of pregnancy or childbirth, and has strongly suggested there is requisite for government and NGOs to work together to provide skilled care at births and timely emergency obstetric care for all women who develop complications. Several factors contribute towards the scenario of low quality health services, among which is the inadequate access to family planning services and demand creation efforts. An unmet need also rests as a key problem in family planning programs. Women need the most nutritional diet during their pregnancy, but the lack of nutrition remains one of the major issues in rural areas of the country (Nel, Binns, \& Bek, 2007).

\section{Role of NGOs in Advocating Reproductive Health: Malaysia vs Nigeria}

The weighty role of Malaysian civil organizations in developing communities cannot be denied (Musa, 2002; Navaratnam, 2003; Schak, 2003). Various funding prejects were awarded by US foundtions (Nahan, 2003; 


\section{Y hternational Research Journal}

p-ISSN 2202-2821 e-ISSN 1839-6518 (Australian ISSN Agency)

Nunnenkamp et al 2009). Mike (2003) points out that US based foundations had funded Malaysian NGOs with 59 grants valued at more than US\$ 4.93 million that focused on various fruitful service delivery projects, besides lobbying purposes and environmental issues. Regardless of the diverse ethnic background, organizational outlook, working structures, organizational size and practices, these NGOs as a whole are still making effort for the betterment of the society (Nalini, 2002; Vidhu, 2002; Saw \& Kesavapany, 2006).

The Federation of Reproductive Health Association of Malaysia (FRHAM) is one among the oldest and leading organizations dealing with voluntary family planning and reproductive health issues in Malaysia. As a service-oriented organization, FRHAM has the community at heart with sexual and reproductive health being the most important areas of focus for serving the community (FRHAM, 2013).

As a country overburdened with multi-sectoral problems (Rosenberg, Hartwig, \& Merson, 2008), Nigeria receives funding through the NGOs for its several out-reach projects (IRIN News-Botswana, 2006). Studies show that the rightsbased development (RBD) organizations are rising in Nigeria (Manzo, 2003) as the role of prominent international institutions such as the United Nations (UN), International Development Agencies (IDAs), and the World Bank have been noticeable (Rosenberg et al., 2008). The role of the mentioned organizations can be witnessed in educational development, social mobilization, health issues, democracy and governance, youth rehabilitation, agricultural development, rural development and reproductive health (UNFPA, 2013).

In fact, the NGOs are playing significant role to serve communities (Benowitz, 2001; Frank, 1999; Keith, 2005; Keohane, 2002). However, NGOs in Nigeria are yet to come together as a cohesive and powerful agent of change. This calls for the role of NGOs to be augmented to help prevent unsafe and unnecessary abortions, maternal and neonatal death, and transmission of HIV to newborns (UNFPA, 2013; NFD, 2014). Reproductive health is the one of the key issues in the country so NGOs are focusing mostly on this problem. Yet there is a strong requirement for NGOs working in Nigeria to work in a way so that their efforts can complement each other's work (Manzo, 2003).

\section{Communication Models of Reproductive Health NGOs: Malaysia vs Nigeria}

Established in 1958, the Federation of Reproductive Health Associations Malaysia (FRHAM) that was formerly known as The Federation of Family Planning Associations Malaysia (FFPAM) is one of the oldest active organizations
Vol. 10 No. 012020

82801001202007

of the country. "Since 1963, FRHAM has been a member of the International Planned Parenthood Federation (IPPF) and became a fully accredited member in November 2005" (Report 2010 p.13). Currently this organization serve in all the 14 states with a focus on reproductive health and rights in Malaysia. The aim of FRHAM are educating Malaysians in family planning and responsible parenthood, promoting and supporting effective family planning and providing sexual and reproductive health services. Various studies have also been conducted on attitudes and practices of men and women on family planning, sexual and reproductive health issues and HIV/AIDS (FRHAM 2012).

Figure 1 (see below) denotes that FRHAM has two communication models; one with the state level reproductive health association and the other with communities. The state reproductive health associations were formed to work in their respective states because it looked difficult for FRHAM to mobilize communities of other states directly (FRHAM, 2013). Organizational literature and reports highlighted that in the 90s, FRHAM started working with communities in Selangor state, directly. Therefore, it was necessary to set two communication channels one with the associations of different states and other with communities and stakeholders.

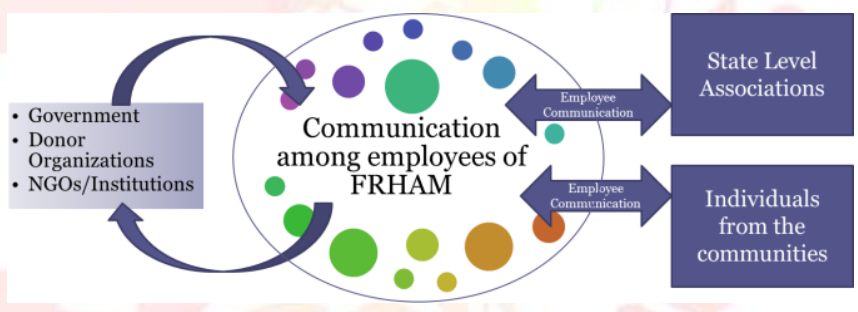

Figure 1: Communication Model of FRHAM (FRHAM, 2012, p.4)

The Association for Reproductive and Family Health (ARFH) is one of the leading indigenous non-profit organizations in Nigeria and is committed to improve the quality of life of underserved and vulnerable communities by promoting access to quality health care and harnessing community capacities for sustainable development (ARFH, 2014; Ladipo, 2013). The organization acts in line with the motto 'working together, building a healthier future' and within its 24 years of existence, has successfully designed, implemented, and managed innovative reproductive health and developmental projects in all the states across the Federation and neighboring countries; most of which had gained national recognition and are being replicated nationwide (O. A. Ladipo \& Delano, 2013). 


\section{Sampling}

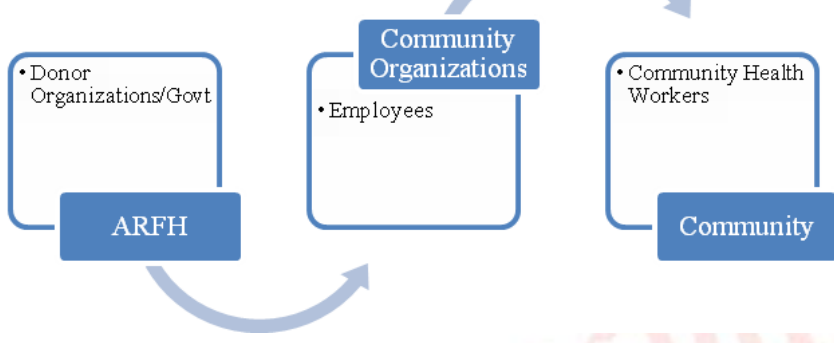

Figure 2: Communication model of ARFH (ARFH, 2013 p.24)

Figure 2 above illustrates the communication model of ARFH. It is seen that initially, the government and donor organizations communicate with ARFH and then the information and activity plans are being communicated with employees (personnel). These employees then work in fields with community organizations; who are the key stakeholders to work in communities. The community organizations further transfer the information and knowledge to community healthcare workers serving in healthcare centers, which are established in rural areas by ARFH. These healthcare centers and the community health workers are directly linked to the community members.

\section{Research Method}

\section{A. Research Design}

The present study has adopted a mixed-method (quantitative-qualitative) research design to identify the potential communicative practices of NGOs advocating reproductive health; particularly the FRHAM in Malaysia and the ARFH in Nigeria, further investigate the similarities and differences of communication norms in both these NGOs, and highlight the key to successful action in low resource settings. This research focuses mainly on the comparison of communication mechanisms at both these NGOs, as being developing nations; they tend to utilizes similar approaches in commutating at the managerial front.

\section{B. Instruments}

A questionnaire was developed to collect statistical data. The items in the questionnaire were categorized under four main themes, namely knowledge and information sharing, consultation and decision making, communication, and networking. Upon discussion with field experts, the 41 items questionnaire was pilot tested with a sample of 30 students. Also, piloting was conducted for the structured interviews with the same respondents. As a result, the questionnaire and interview guide were revised and a good reliability index was obtained.
A purposive sampling through a random selection technique was employed for data collection. Table 1 presents the sample size of respondents. Total employees working in the FRHAM are 36 and ARFH has 42. However, the total number of employees who participated in the study are 40 $(n=40)$. There were 20 respondents from each NGO, accumulating to $56 \%$ from FRHAM and $48 \%$ from ARFH.

\begin{tabular}{l|lll}
\multicolumn{4}{c}{ Table 1: Sample Size of the Study } \\
DESCRIPTION & FRHAM & ARFH & TOTAL \\
\hline TOTAL EMPLOYEES & 36 & 42 & 78 \\
$\begin{array}{l}\text { EMPLOYEES WHO } \\
\text { PARTICIPATED IN THE STUDY } \\
\text { PERCENTAGE }\end{array}$ & 20 & 20 & 40 \\
& $56 \%$ & $48 \%$ & $52 \%$
\end{tabular}

\section{Data Collection}

Two NGOs advocating reproductive health; each from Malaysia and Nigeria respectively were selected for the indepth study, specifically the Federation of Reproductive Health Associations of Malaysia (FRHAM) in Malaysia and the Association for Reproductive and Family Health (ARFH) in Nigeria. The data was collected through questionnaire and interviews. Communication norms and ways of getting employees and communities involved in their projects were also observed through progress reports, document reviews and web searches. Reports and other material were also collected from websites of both these NGOs. FRHAM also shared the printed materials of the organization. A lot of information pertaining the NGOs that were available online in PDF version. It was saved for reference purposes.

\section{E. Data Analysis}

Upon disseminating the questionnaires and gathering data from the personnel at both the NGOs selected, the quantitative data was analysed using SPSS software and presented in graphical form. Multiple regressions were also done for further statistical analysis. The paper discusses how information sharing, consultation and decision-making, communication as well as networking are done by these selected NGOs in Malaysia and Nigeria.

\section{Findings}

\section{A. Knowledge and Information sharing}

Knowledge and information sharing is one of the most important functions in organizational management. Nongovernmental Organizations (NGOs) rely greatly on proper information and knowledge sharing. 


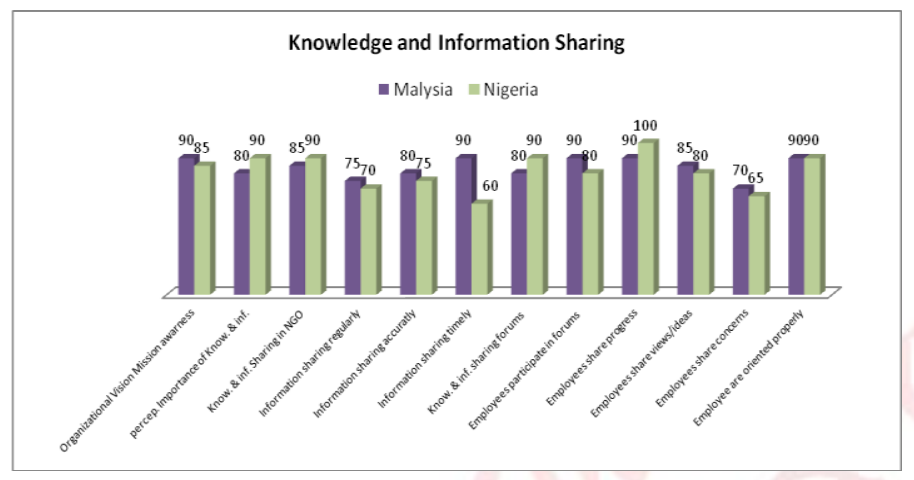

Figure 3: Knowledge and Information Sharing

Figure 3 shows that $90 \%$ of Malaysian and $85 \%$ of Nigerian NGO employees have remembered the vision and mission statement of their organizations. $80 \%$ of Malaysian and $90 \%$ of Nigerian personnel realize the importance of knowledge and information sharing in the organizations. $85 \%$ of Malaysian and $90 \%$ Nigerian participants have mentioned that the information is shared with them. $75 \%$ Malaysian and $70 \%$ Nigerian NGO employees said that information is shared on a regular basis. $80 \%$ Malaysian and $75 \%$ Nigerian respondents stated that the information shared was accurate. 90\% Malaysian and 60\% Nigerian respondents confirmed that the information and reports were shared on time. This suggests that timely information sharing has not been practiced by the ARFH. The Nigerian NGO should keep in mind that information not delivered in time, loses its credibility.

As for the availability of forums where employees can share their views, 80\% Malaysian and 90\% Nigerian employees replied that there were forums for them to take part which in turn reflects the information flow that exist in both NGOs. Employee participation ratio at these forums is $90 \%$ for the Malaysian NGO and $80 \%$ for the Nigerian NGO. $90 \%$ Malaysian and $100 \%$ Nigerian NGO employees share their progress at the forums while $85 \%$ Malaysian and $80 \%$ Nigerian NGO employees share their views/ideas. As for problem sharing, it is learnt that $70 \%$ Malaysian and $65 \%$ Nigerian NGO employees share their concerns/problems at these forums. Generally, when the employees are not provided an opportunity to share their concerns, they tend to lose their sense of belonging. On the other hand, if they are provided this opportunity, higher management would then gain the opportunity to address these problems and project management may be strengthened.

\section{B. Consultation and Decision Making}

Consultation and decision-making are key functions of NGOs. Several community development experts emphasize the importance of their employees' consultation and decision-making. Moreover, these variables are taken as the indicators of employees' empowerment.

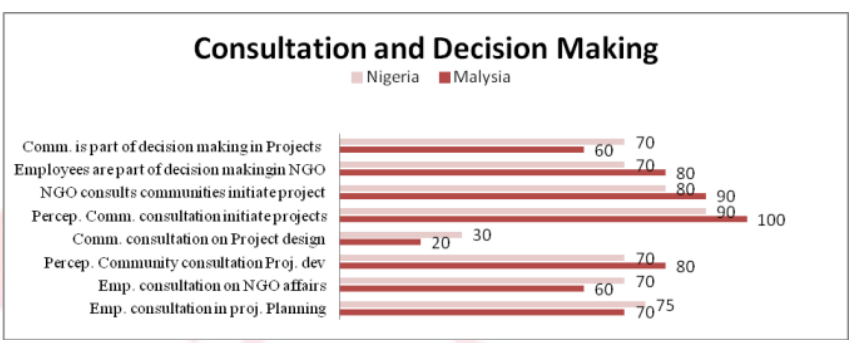

Figure 4: Consultation and Decision Making

Figure 4 shows the consultation and decision making mechanisms in NGOs of both countries. 70\% Malaysian and $75 \%$ Nigerian employees are consulted and become part of project planning. 60\% Malaysian and 70\% Nigerian NGO employees are consulted on NGO affairs. 80\% Malaysian and $70 \%$ Nigerian employees said that at the time of project development, communities should be involved in the consultation and decision-making. It appears that the NGO employees are not consulted properly in the planning of the organizations. Such a bureaucratic approach harms organizations. In today's world of organizational management, participatory management is essential. The organizations, which follow such an approach benefit from collaborative planning to clear goal setting which then leads to a strengthened and healthy planning for their organization.

Organizational planning is a roadmap for any organization. In fact, if the direction is clear, then it becomes very easy to achieve its required goal. However, only 20\% Malaysian and 30\% Nigerian personnel confirmed that these NGOs consult with communities at the time of project development. It points out that community is not consulted during project planning. Both organizations seem to develop their projects based on their perceived needs. Various scholars and the international organizations such as UNDP, UNICE and World Bank discourage such proposals and project approach in which there is no community participation ensured at initial phase. Sustainability of any project relies on effective communication and participation by the community members during project development. However, both these organizations suggested that they should streamline their project development strategy. Otherwise they will face difficulties in sustaining their projects with community. The projects should be developed in accordance with needs and demands of the community members. This is because the community will only participate in activities where their participation and needs would be addressed accordingly. 


\section{Yimternational Research Journal}

p-ISSN 2202-2821 e-ISSN 1839-6518 (Australian ISSN Agency)

Furthermore, $100 \%$ Malaysian and $90 \%$ Nigerian respondents stressed that the community should be consulted when NGOs initiate their projects. $90 \%$ Malaysian and $80 \%$ Nigerian employees said that communities are consulted. Here the realization of the NGO employees is clearly felt. It means that the employees wish that the communities should be consulted before making any project proposal but the practice is thoroughly reversed. The leaders of both the organizations should notice the voice of employees at the initial stages of project planning. $80 \%$ Malaysian and $70 \%$ Nigerian employees were part of decision making on the NGO affairs. On the other hand, only $60 \%$ Malaysian and $70 \%$ Nigerian community members are the part of decision making on NGO projects.

Participatory decisions are the key source to success of any plan. In these both NGOs, mostly the higher management makes its decisions. The employees are there just to follow the decisions. NGOs are with the people and for the people. It means that the people who work for the people (community individuals). If the employees are not be the part of the decision making process, they will tend to disown themselves from organizational affairs and would only be working like robots by just taking instructions. The leaders on the other hand would only be able to see the community problems from the managerial point of view. If the participation is improved in the decision making phase, it may result in the increased sense of belonging. Both these NGOs have decided to critically review their communication management system and ensure the participation of their employees in their organizational decisions. In this way, employees would be empowered.

\section{Communication}

Communication plays a significant part in the success of NGO projects. In this research, communication is seen as a key undertaking for management in both NGOs.

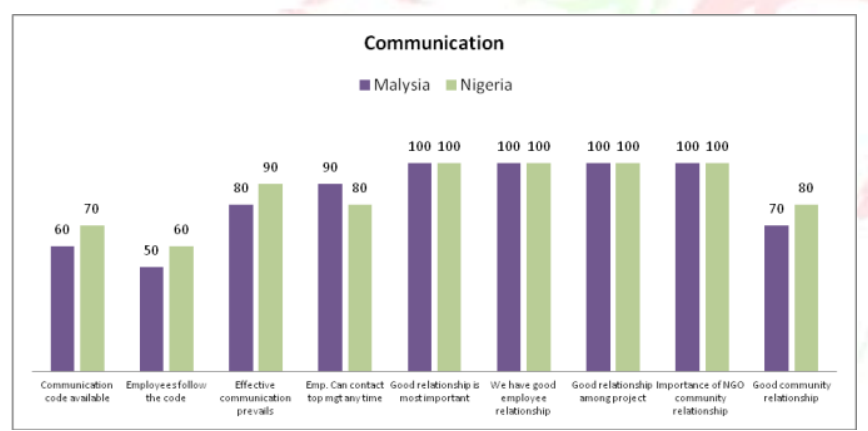

Figure 5: Communication

Figure 5 shows the communication system which is in placed among the NGOs. $60 \%$ Malaysian and $70 \%$ Nigerian respondents said that a communication code of conduct was
Vol. 10 No. 012020

82801001202007

available in the NGO. 50\% Malaysian and 60\% Nigerian employees responded that they follow the code of conduct. It appears that the protocols and Standard Operating Procedures (SOPs) exist in NGOs but the knowledge and information of these systems is shared with limited number of employees of the organization. Only the senior employees; those who are working for more than 10 years seem to be familiar with the SOPs. This might be the fulfilment to show the donor organizations that NGOs have sound system.

Nevertheless, here the organizations suggested that such important code of conduct documents should be shared with all employees at the time of their organizational orientation when they initially join. 80\% Malaysian and 90\% Nigerian respondents stated that there was effective communication within their NGOs. 90\% Malaysian and 90\% Nigerian respondents said that they are allowed to contact their top management at any time. These are good signs that the employees are allowed to contact with their higher management any time. This reflects that open door management policy is practiced in both NGOs just to ensure the proper management flow. It was confirmed by all the respondents in both countries that there was a good relationship among employees when working in different projects. Similarly, $100 \%$ of employees of both NGOs realized the importance of community relationship while only $70 \%$ Malaysian and $80 \%$ Nigerian employees said that they had good relations with the communities in which the NGOs are involved.

\section{Networking}

Lately, there have been several networking forums established by the NGOs and governmental organizations. In the present times, networking is considered one of the most important functions of an organization as networks support their member organizations at different levels and on various issues in society.

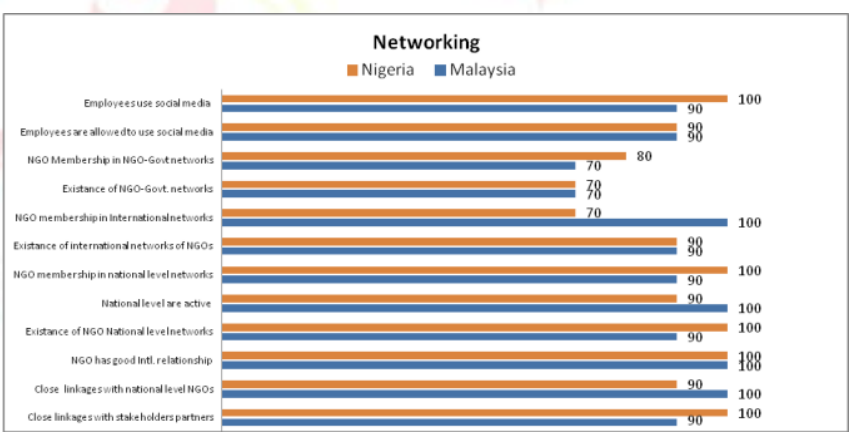

Figure 6: Networking

Figure 6 shows the networking of NGOs in both countries. $90 \%$ Malaysian and $100 \%$ Nigerian respondents said that 
they have close linkages with the stakeholders and their partner organizations. 100\% Malaysian and 90\% Nigerian NGO officials stated that they have also good linkages with the national level organizations. All NGOs respondents at both the NGOs responded that their organizations have good linkages with international networks. 90\% Malaysian and $100 \%$ Nigerian NGO respondents confirmed that national level networks have been established accordingly. 100\% Malaysian and $90 \%$ Nigerian NGO participants said that these networks play active roles. The networking of both NGOs seems sound and the organizations are making conscious efforts in this regard. Networking has various advantages if given proper attention.

Furthermore, $90 \%$ Malaysian and 100\% Nigerian respondents mentioned that their NGOs are part of these national level networks. The $90 \%$ respondents of both these NGOs said that international networks have also been established. 100\% Malaysian and 70\% Nigerian employees said that their NGOs are part of these international networks. The $70 \%$ respondents of both these NGOs stated that the governments of both countries have also formed government-private partnership networks. The $70 \%$ Malaysian and $80 \%$ Nigerian respondents said that the NGOs are part of the government formed networks. These findings show that international organizations and the governments have formed their networks to coordinate with NGOs working for community development in the respective countries. Doubtlessly, these coordinated efforts create an enabling environment for the organizations. Even the duplication of work and wastage of resources could be avoided through effective networking.

The $90 \%$ of both NGOs' respondents also said that they are allowed to use the social media while $90 \%$ Malaysian and $100 \%$ Nigerian employees confirmed that they did use social media. Social media can be used as an instrument for gathering and sharing the information. Both NGOs are advised to have their own employees' group and share the relevant information in just a click. NGOs can save sufficient time, energy and resources by using social media effectively.

\section{E. Multiple Regression Results}

Table 2 shows the $\mathrm{R}$ and $\mathrm{R}$ square values are 0.974 and 0.948 . The $\mathrm{R}$-value, which is almost $98 \%$, reflects a positive relationship between the independent and dependent variables. The adjusted R2 is $0.835(84 \%)$.

\begin{tabular}{lllll} 
& \multicolumn{4}{c}{ Table 2: Model Summary } \\
MODEL & $R$ & $R$ & ADJUSTED R & STD. ERROR OF \\
& & SQUARE & SQUARE & THE ESTIMATE
\end{tabular}

The Table 3 depicts the degree of freedom with a goodness fit of 13. The output illustrates the value of $F$ as 8.4 with significance $\mathrm{p}$ values of 0.008 ; which is greater than 0.05 .

\begin{tabular}{r|rrrrrr} 
MODEL & \multicolumn{1}{l}{$\begin{array}{l}\text { SUM } \\
\text { SQUARES }\end{array}$} & OF & DF & \multicolumn{1}{l}{$\begin{array}{l}\text { MEAN } \\
\text { SQUARE }\end{array}$} & F & SIG. \\
\hline \multirow{2}{*}{$\mathbf{1}$} & Regression & 4.549 & 13 & 0.350 & 8.376 \\
& Residual & 0.251 & 6 & 0.042 & \\
& Total & 4.8 & 19 & & \\
& & & & &
\end{tabular}

Table 4 reflects beta value for dependent and independent variables. The table displays the 'follow code of conduct': 0.038, 'linkage of NGO's leadership at international level': 0.013, 'effective linkages among employees': 0.046, and 'flow of communication in NGO': 0.013 as they are significant and their $\mathrm{p}$ value is less than 0.05 . The $\mathrm{p}$ value of less than 0.05 reflects the significance of independent variables compared to the dependent variable. Further, the table illustrates 'code of conduct on communication': 0.399, 'frequency of contacting employees with higher management': 0.409 and 'using social media to build social networks in NGO': 0.558 . Thus, the dependent variable is effective communication.

\begin{tabular}{|l|c|c|c|c|c|c|}
\hline \multicolumn{2}{|c|}{ Model } & $\begin{array}{c}\text { Un-standardized } \\
\text { Coefficients }\end{array}$ & Standardized Coefficients & \multirow{2}{*}{ T } & Sig. \\
\cline { 2 - 6 } & B & $\begin{array}{c}\text { Std. } \\
\text { Error }\end{array}$ & Beta & & 0.810 & 0.449 \\
\hline \multicolumn{1}{|c|}{ (Constant) } & 0.568 & 0.701 & & 0.907 & 0.399 \\
\hline $\begin{array}{l}\text { Communication } \\
\text { code available }\end{array}$ & 0.067 & 0.074 & 0.134 & -2.649 & 0.038 \\
\hline $\begin{array}{l}\text { Follow code of } \\
\text { conduct }\end{array}$ & -0.242 & 0.091 & -0.380 & -0.887 & 0.409 \\
\hline $\begin{array}{l}\text { Any time } \\
\text { employees contact } \\
\text { with top } \\
\text { management }\end{array}$ & -0.053 & 0.060 & -0.105 & 3.519 & 0.013 \\
\hline $\begin{array}{l}\text { Top leadership of } \\
\text { NGO have } \\
\text { linkages at } \\
\text { international level }\end{array}$ & 0.662 & 0.188 & 0.644 & -0.621 & 0.558 \\
\hline $\begin{array}{l}\text { using social media } \\
\text { for strengthening } \\
\text { networking in } \\
\text { NGO }\end{array}$ & -0.126 & 0.203 & -0.143 & -3.485 & 0.013 \\
\hline $\begin{array}{l}\text { Prevailing the } \\
\text { effective } \\
\text { communication in } \\
\text { NGO }\end{array}$ & -0.633 & 0.182 & -0.807 & & & \\
\hline
\end{tabular}

\section{V.Discussion and Conclusion}

The paper began with the discussion of the notion of NGOs and the state of reproductive health in Malaysia and Nigeria, followed by the role of these NGOs and their communication models respectively. Knowledge and 


\section{Yinternational Research Jourmat}

p-ISSN 2202-2821 e-ISSN 1839-6518 (Australian ISSN Agency)

information sharing, consultation and decision-making, communication and networking were taken as key variables in the study. Based on the findings it is clear that that for the most, the employees of both the NGOs are aware of their organizations' mission statement. It is a positive sign that the organizations are successfully conveying their mission statement to their employees. Employees of both NGOs are also aware of the importance of this. Information sharing is occurring on a regular basis but with a tendency to be a bit late. This delay in disseminating such important information means that the importance of sharing information is not fully comprehended. It is highly recommended that these organizations understand the importance of disseminating information on a timely basis. The Malaysian NGO shares information on time as compared to the Nigerian NGO, which does not. Perhaps the Nigerian NGO faces some challenges in so doing. There is a need to learn from the Malaysian NGO on how this is accomplished.

A code of conduct is like an anchor that provides clear guidelines so that employees can communicate smoothly. It is learnt that only the senior employees had knowledge about the code of conduct. The NGOs should emphasize that it is vital that all employees know the code of conduct. At the time of initiation or orientation of employees, this code of conduct should be shared with them. Both NGOs have established forums where employees share their progress, concerns, ideas, suggestions and feedback. Such an information sharing system strengthens the relationship among and between employees. When fewer employees share their problems and issues in these forums and if views and problems are not handled wisely, the higher management will not be able to make knowledge-based decisions ultimately.

Employees of both NGOs appeared to be made part of the consultation and decision making process pertaining to projects and organizational affairs. However, the participation of employees in organizational decisionmaking was rather limited as the higher management makes most decisions. This study highlights that participatory management is preferred and organizations need to review their decision making model. The NGOs in both countries also do not consult with communities at the time a project is initiated. Such a practice may adversely affect project sustainability. Various international organizations and donors insist that project proposals should be developed with the consultation of communities. However, it appears that the NGOs make the proposals on their own perceived needs and not the real needs of their respective communities. If the community does not become part of the process, the need identified may not be valid. While communities may
Vol. 10 No. 012020

82801001202007

tend to avoid participation in NGO activities, it is suggested nonetheless, that they should be consulted. These organizations seriously adopt good communication and networking with other stakeholders such as other NGOs, donor organizations, international forums, national and international level networks.

This study found that the flow of communication is different in both these NGOs. AFRH's working system and communication model is linked with community organizations, and community health workers while the FRHAM implements two communication models, one with the State level reproductive health association and second direct with the communities. The model of FRHAM is an exemplary model for the African NGO. The model of FRHAM strengthens and empowers the smaller organizations so that they can work independently. In reality, all these associations are working on their own, though they are being supported by government and various donor organizations. In the Nigerian NGO context, AFRH works directly with community organizations; quite an expensive working approach, as a large number of employees are required to implement the projects in rural areas. Based on the results of this study, it is only wise that AFRH should learn from the FRHAM's working approach. The findings of the study will not only benefit the NGOs discussed but also other NGOs advocating reproductive health in other parts of the world. All NGOs can learn and improve their management systems by ensuring the best of practices to sustain effective communication.

\section{REFERENCES}

1. Ajibade, Y. (2009). Functional Communication in Non-Governmental Organizations: Challenges for Post-literacy Development and Language Education Opportunities. International NGO Journal. 4 (9), pp. 375-379

2. Amin, M. R. (2009). A Documentary Report on NGOs in Bangladesh: The Case Study of UDDJPAN. Dhaka: Department of Public Administration University of Dhaka.

3. ARFH. (2014). Introduction of ARFH. Retrieved 12 January, 2018, from http://arfh-ng.org/about.php

4. Benowitz, E.A. (2001). Principles of Management. New York: Hungry Minds, Inc.

5. Budden, M.C. (2010). Developing Crisis Management Skills Through A Realistic Case Scenario.

6. Burger, R., (2012). Reconsidering the Case for Enhancing Accountability Via Regulation. VOLUNTAS: International Journal of Voluntary 
and Nonprofit Organizations, 23(1), 85-108. doi: 10.1007/s11266-011-9238-9

7. Candland C., (2001) Institutional Impediments to Human Development in Pakistan. In: Shastri A., Wilson A.J. (eds) The Post-Colonial States of South Asia. Palgrave Macmillan, New York

8. Edwards, M. (1994). NGOs in the age of information. IDS Bulletin, 25(2), 117-125.

9. Frank, F \& Smith, A. (1999). The community development handbook : a tool to build community capacity. Human Resources Development Canada, Hull, Quebec

10. FRHAM. (2018). Introduction of FRHAM. Retrieved March 26, 2018, from http://www.frham.org.my/

11. Goldberger, J.R. (2008). Non-governmental organizations, strategic bridge building, and the "Scientization", of Organic Agriculture in Kenya. Agriculture and Human Values, 25(2008), 271-289.

12. Hilhorst, D. (2003). The Real World of NGOs. Discources, Diversity, and Development. London: Zed Books Ltd.

13. Keith, G. (2005). The Sociology of Work (3rd ed.). Cambridge UK: Polity Press.

14. Keohane, R. O. (2002). Power and Governance in a Partially Globalized World London: Routledge.

15. Komito, L. (2007). Community and Inclusion: The Impact of New Communications Technologies. Irish Journal of Sociology. 16. $10.1177 / 079160350701600205$.

16. Kumar, N. 2002. The challenges of community participation in forest development in Nepal (English). Operations Evaluation Department (OED) working paper series. Washington DC. World Bank.

17. Ladipo, O.A., \& Delano, G. E. (2013). Annual Report (Vol. 01). Abuja ARFH.

18. Lim, H., \& Chee, H. L., (1998). Nutritional status and reproductive health of Orang Asli women in two villages in Kuantan, Pahang. Malaysian journal of nutrition. 4. 31-54.

19. Manzo, K. (2003). Africa in the rise of rights-based development. Geoforum, 34(4), 437-456. doi: 10.1016/s0016-7185(03)00048-4

20. Mian, L. H., \& Leng, C. H. (1998). Nutritional status and reproductive health of Orang Asli women in two villages in Kuantan, Pahang. Malaysian Journal of Nutrition, 4(4), 31 - 54.

21. Mike, N., (2003). US Foundationa Funding in Malaysia (Vol. 1). Melbourne: Institute of Public Affairs.
22. Musa, B. (2002). Malaysia: In the era of globalization. New York: Writers Club Press.

23. Nahan, M. (2003). US Foundational Funding in Malaysia (Vol. 1). Melbourne: Institute of Public Affairs.

24. Nalini, K. (2002). The Challenges of Community Participation in Forest Development in Nepal. Washington, D.C: The World Bank.

25. Navaratnam, R. V., (2003). Malaysia's Economic Challenges: A Critical Analysis of the Malaysian Economy Governance and Society. London: Asean Academic Press Ltd.

26. Nel, E., Binns, T., \& Bek, D. (2007). 'Alternative foods' and community-based development: Rooibos tea production in South Africa's West Coast Mountains. Applied Geography, 27(2), 112-129. https://doi.org/10.1016/j.apgeog.2006.11.001

27. News, IRIN. (2006). 'South Africa: Government adopts more focused approach to help orphans', IRIN. $\quad$ Retrieved from www.irinnews.org/report.asp?ReportID $=51835 \mathrm{~S}$

28. NFD. (2014). Directory of NGOs Nigeria. Retrieved 12 January 2014, from http://web.nnngo.org/membership/mlist.htm

29. Nour, A. (2011). Challenges and Advantages of Community Participation as an Approach for Sustainable Urban Development in Egypt. Journal of Sustainable Development, 4(1), 79-91.

30. Nunnenkamp, P. \& Weingarth, J. \& Weisser, J. (2009). Is NGO Aid Not So Different After All? Comparing the Allocation of Swiss Aid by Private and Official Donors. European Journal of Political Economy. $25.422-438$. 10.1016/j.ejpoleco.2009.01.001.

31. Paul, H., \& Ilona, V. (2010). Community Development and Civil Society; Making connection in the European Context. Portland: The Policy Press.

32. Rahman, A.R \& Ibrahim, M. \& Salleh, H. \& Ismail, S. \& Ali, S. \& Manan, W. \& Ishak, M. \& Ahmad, A. (2011). Knowledge of Sexual and Reproductive Health among Adolescents Attending School in Kelantan, Malaysia. The Southeast Asian journal of tropical Medicine and Public Health. 42. 717-25

33. Roni, S., (2009). Community Anti-Poverty Strategies: A Conceptual Framework for a Critical Discussion. British Journal of Social Work, 39, 1063-1081.

34. Rosenberg, A. \& Hartwig, K. \& Merson, M. (2008). Government-NGO collaboration and 
sustainability of orphans and vulnerable children projects in southern Africa. Evaluation and program planning. 31 51-60. 10.1016/j.evalprogplan.2007.08.005.

35. Rule, A. \& Kyle, P. (2009). Community-Building in a Diverse Setting. Early Childhood Education Journal. 36. 291-295. 10.1007/s10643-008-0290-z.

36. Ruth, P. (2006). The Role of Nonprofit Advocacy Organizations in Australian Democracy and Policy Governance International Journal of Voluntary and Nonprofit Organizations, 17(01), 59-75.

37. Salim, L. \& Sadruddin, S. \& Zakus, D. (2012). Organizational Commitment in a Health NGO in Pakistan. VOLUNTAS: International Journal of Voluntary and Nonprofit Organizations. 23. 10.1007/s11266-011-9209-1

38. Saw, S.H, \& Kesavapany, K. (2006). Malaysia Recent Trends and Challenges. Singapore: Institute of Southeast Asian Studies.

39. Schak, D. C., \& Hudson, C. (2003). Civil society in Asia. In D. C. Schak, \& W. Hudson (Eds.), Civil society in Asia (1 ed., pp. 1-8). Ashgate Publishing Limited.

40. Scholes, E. (1998). Gowere Handbook of Internal Communication. Hampshire England Gower Publishing Limited.

41. Smith, F., and Anne. (1999). The Community Development Handbook a tool to build Community Capacity Alberta: Learning and Development Canada.

42. State, U.S.D., (2006). Country reports on human rights practices 2005. Washington DC: US Department of State.

43. Tanova, C., \& Nadiri, H. (2010). The role of cultural context in direct communication. Baltic Journal of Management, 5(2), 185-196.
44. Terri, S., \& Jennifer, N. G., (2006). Effect of communication mode in justice-based service recovery. Managing Service Quality, 16(2), 124144.

45. UNFPA. (2013). Reproductive Health Problems in Nigeria. Retrieved 26 December 2013, from http://nigeria.unfpa.org/reproductivehealth.html

46. Vidhu, V. (2002). Malaysia State and Civil Society in Transition. London Lynne Rienner Publishers, Inc.

47. Yadav, S. (2018). Growing Human Population and Sustainable Development. IARS' International Research Journal, 8(1). Retrieved from https://researth.iars.info/index.php/curie/article/vie w/87

48. Shukla, B., \& Kaur, D. (2013). A quasiexperimental study to assess the effectiveness of structured teaching programme on knowledge regarding prevention of STDs among women in the selected rural areas, Hoshiarpur, Punjab â€“" India. IARS' International Research Journal, 3(2). Retrieved from https://researth.iars.info/index.php/curie/article/vie w/30

49. Eynul-din, H. K., Ahmadi, A., \& Ahmadi, S. (2015). Social and Economic Sustainability Analysis of Rural Settlements Located in the Hazard-Prone Areas: Case Study: Villages Surrounding the City of Sanandaj. IARS' International Research Journal, 5(2). Retrieved from https://researth.iars.info/index.php/curie/article/vie w/52 